\title{
G140011
}

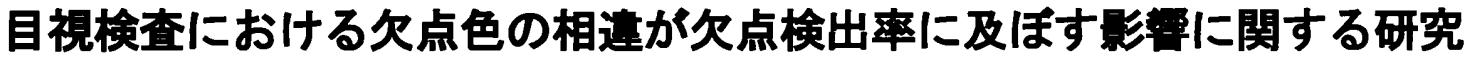

\author{
康 秀徳 ${ }^{* 1}$, 中嶋 良介 ${ }^{* 1}$, 市毛 貴博 ${ }^{* 1}$, 志田 敬介 ${ }^{* 2}$
}

\section{A study on the effect of a difference between defect colors on detection rate in visual inspection}

\author{
Hidenori $\mathrm{KOH}^{* 1}$, Ryosuke NAKAJIMA, Takahiro ICHIGE and Keisuke SHIDA \\ ${ }^{* 1}$ Nagaoka University of Technology . Dept. of Management and Information System Engineering \\ Kamitomiokamachi 1603-1, Nagaoka-shi, Niigata, 940-2137 Japan
}

In the manufacturing industry, it is common to conduct visual inspection in order to ensure the quality of products external appearance. Visual inspection is one of the sensory evaluations by means of human sensation. Since there is dispersion in the result of the inspection according to the suitability and the experience of the worker, the standardization of the work is a problem to be solved. Therefore, in order to quantify the work of visual inspection, in this paper, the effect of the difference of the defect color on detection rate is examined. Specifically, an experiment was done with luminance and hue of the defect as variation factors. As a result, the detection rate of defects with same hue increases with the increase in the luminance difference of background and defect. Moreover, the detection rate of defects with same luminance increases with the increase in yellow-blue component of the background and defect

Key Words : Visual Inspection, Peripheral vision, $\mathrm{L}^{*} \mathrm{a}^{*} \mathrm{~b}^{*}$ color system, color component

\section{1. 精}

日本の生産現場では，市場への不良品の流出を防止するため，製品の検查が徹底的に行われている．検査は機 能検査と外観検査とがある．機能検查は製品の動作を確認することで，良品か不良品かの判別ができるので，自 動化が進んでいる，一方，外観検査はキズや污れの大きさや濃さ，色，凹凸など多様な状態を呈している欠点を 検出し，その程度に合わせて製品が良品か不良品かを判別しなければならず，自動化が困難である．さらに近年 では，製品の小型化や精密化が進み，カメラの分解能を越える欠点の発見が必要な場面も数多く見られる.これ らの問題を解決し, 外観検査の自動化を行うには膨大なコストが必要となることから,多くの生産現場において， 外観検査は人間による目視検査に頼らざるを得ない状況にある.

一般的に，目視検査員には欠点を確実に検出する能力(検出能力)とその欠点を顧客のニーズに基づいた不良判 定基準と比較し，良品と不良品を正確に判断する能力(判断能力)の 2 つが必要である. 我々の先行研究では前者 の検出能力に着目して，様々な種類の欠点が欠点検出率に及ぼす影響について検討した．その結果，背景と欠点 の輝度コントラストと欠点検出率の間に正の曲線的な相関があることが明らかになった．しかし，同輝度でも異 なる複数の色が存在するので，ある輝度コントラストをとる欠点と背景の組み合わせは無数に存在することにな る. その寸べての組み合わせに拉いて欠点検出率が同様になるかは明らかとなっていない. 先行研究でも欠点の 色に一部の限定した色相のみを用いていることから，輝度コントラストだけではなく欠点や背景の色が欠点検出 率に与える影響を検討する必要があると考えられる.

そこで本研究では，輝度と色相の異なる様々な欠点を用いて，ディスプレイ上で目視検査をモデル化した実験 を行い，欠点色の相違が欠点検出に及ぼす影響について検討することを目的とする.

\footnotetext{
*1 非正員, 長岡技術科学大学大学院（T940-2137 新潟県長岡市上富岡町 1603-1）

22 正員, 長岡技術科学大学

E-mail: s103406@stn.nagaokaut.ne,jp
}

[No.12-1] 日本機械学会 2012 年度年次大会講演論文集 [2012.9.9-12.金沢] 


\section{2. 实硂方法}

\section{$2 \cdot 1$ 橦通作举}

課題作業として, 図 1 に示す縦 $1 \mathrm{~cm}, 11.3 \mathrm{~cm}$ の領域に, 直径 $1 \mathrm{~cm}$ の円(以後, 注視点と呼ぶ)を 2 つ配置した検 查対象をモニタに表示した．被験者はまず，上の注視点を注視し，検查対象上部を検查する．次に同様の方法で 検查対象下部を検査し, 1 枚の検查対象の検查が完了する.被験者がEnter Keyを押すと次の検査画面が表示され， 同様の方法で検查を繰り返す．被験者には，上下の注視点のみを注視させ，他の位置を注視しないことを教示し た. ただし，被験者が欠点を検出した場合は，その欠点を注視することを認めており，次点確認後， Space Key を押すことを教示した．なお，指示通り欠点発見時以外は，注視点のみを注視し，周辺視を用いた検查が実施さ れているかを確認するため, 被験者にはアイカメラ(nac 社製 EMR-9)を装着して, 実験を行った. 実験のレイア ウトは，図 2 のうにモニタ(ナナオ社製 FlexScan SX2462W)から 50cm の)位置にアゴ台を設置し，被験者の頭部 を固定した. その際, モニタの中心を正面から注視するように図 2 中※1〜3調整した. また, 蛍光灯による検 査モデルの色変化の影響を考慮し，暗室にて実験を行った．実験では，不良率を $20 \%$ に設定し，2800 枚(内 560 枚が欠点を含む検査対象)を検査する。

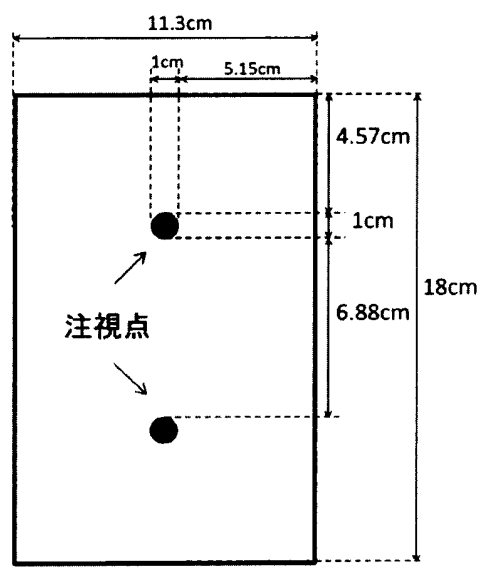

Figure1 Inspection Object

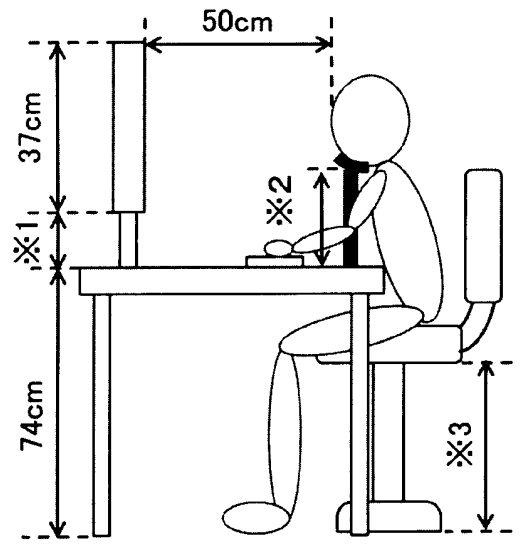

Figure2 Experimental Layout

\section{$2 \cdot 2$ 欠点の样細}

欠点の大きさは視角 $0.1755^{\circ}$ ], 直径 $0.15[\mathrm{~cm}]$ の円を用いた. 背景色と欠点色はともに色差評価で一般的に用い られる $\mathrm{L}^{*} \mathrm{a}^{*} \mathrm{~b}^{*}$ 表色系で定義した. L $\mathrm{L}^{*} \mathrm{a}^{*} \mathrm{~b}^{*}$ 表色系とは明度を $\mathrm{L}^{*}$ ，赤みと緑みの相対的な量を $\mathrm{a}^{*}$ ，黄みと青みの相対的 な量を $\mathrm{b}^{*}$ で表した均等色空間の一つである. 実際の色の決定の際は, 色相を等間隔に変更した色を作成するため に $\mathrm{a}^{*}$ と $\mathrm{b}^{*}$ を極座標変換することによって求めた彩度 $\mathrm{C}^{*}$ と色相角 $\mathrm{h}$ を用いた. 欠点色は, 色㥵角 $\mathrm{h}{ }^{\circ}{ }^{\circ}$ ]を $0^{\circ}$ から $315^{\circ}$ まで $45^{\circ}$ 刻みで変更させた 8 種と輝度コントラスト V を $0.006,0.009,0.012,0.015,0.018$ で変更させた 5 種の全組み合わせとなる 40 種を作成した. 明度 $L^{*}=80$, 彩度 $C^{*}$ は色相角と輝度コントラストの組み合わせごとに 決定した(表 1). なお, 背景色は明度 $\mathrm{L}^{*}=80$, 彩度 $\mathrm{C}^{*}=0$, 輝度 $\mathrm{V}=85.5\left[\mathrm{~cd} / \mathrm{m}^{2}\right]$ の無彩色とした.

Table1 Color saturation $\mathrm{C}^{*}$ of each of the combinations of hue angle and luminance contrast of the defect

\begin{tabular}{|c||c|c|c|c|c|c|c|c|}
\hline$\Delta \mathrm{V}[\mathrm{cd} / \mathrm{m} 2] \backslash \mathrm{h}\left[^{\circ}\right]$ & 0 & 45 & 90 & 135 & 180 & 225 & 270 & 315 \\
\hline \hline 0.006 & 5.8 & 5.5 & 12.3 & 16.7 & 6.0 & 5.5 & 10.7 & 17.3 \\
\hline 0.009 & 8.6 & 8.2 & 19.2 & 25.0 & 9.0 & 8.2 & 15.6 & 26.3 \\
\hline 0.012 & 11.5 & 11.0 & 27.0 & 33.0 & 12.0 & 10.9 & 20.2 & 35.4 \\
\hline 0.015 & 14.1 & 13.7 & 35.5 & 41.0 & 15.2 & 13.6 & 24.6 & 44.8 \\
\hline 0.018 & 16.8 & 16.4 & 45.3 & 49.0 & 18.3 & 16.3 & 32.8 & 54.6 \\
\hline
\end{tabular}




\section{3. 实硂結果}

欠点の色相角の相違が欠点検出率に及ぼす影響について検討するために, 輝度差と色相角を要因とした 2 元配置の 分散分析をおこなった. その結果, 輝度コントラスト $[\mathrm{F}(4,440)=218.43]$, 色相角 $[\mathrm{F}(7,440)=54.13]$ の主効果, およびこれら 2 要因間の交互作用 $[\mathrm{F}(28,330)=3.94]$ に 1\%水準で有意な差が認められた. また, 交互作用の奏態を図 3 に, 被験者間の ばらつきを標準偏差で図 4 に示す. 図 3 より，すべての色相角において, 輝度コントラストが大きくなるにつれ検出率は高 くなった. また, すべての輝度コントラストにおいて, 検出率は色相角 0,180 付近が極小值, 色相角 90, 315 付近が極大 值となり、その傾向は輝度コントラストが大きくなるにつれ顕著にみられた. 図 4 より, 検出率の低い輝度コントラスト 0.003，0.006 では被験者間のばらつきは小さく，その傾向は検出率と同様であったが，検出率の高い輝度コント ラスト $0.009 ， 0.012 ， 0.015$ では被験者のばらつきは大きく，色相角に関係なく一定の值をとった．

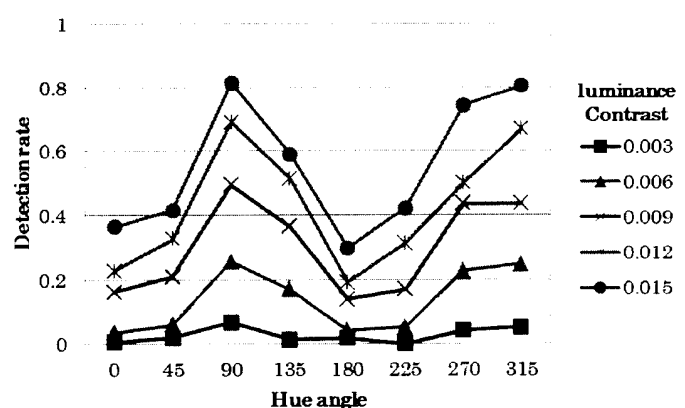

Figure3 Relationship between hue angle and detection rate of each luminance contrast

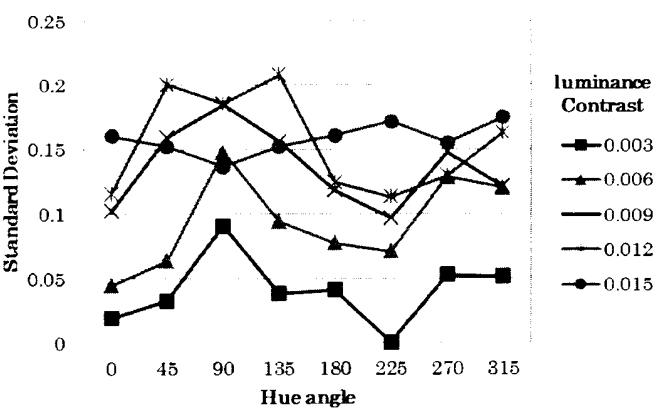

Figure4 Relationship between hue angle and Standard Deviation of each luminance contrast

\section{4. 考察}

欠点の色が検出率に与える影響を詳しく検討するため, 人間の色覚メカニズムに基づく分析を行った．人間は 白対黒, 赤対緑, 黄対青の 3 種類の受容器ともいうべき細胞を持っている. 明るさの感営は向対黒の組織によっ て決定され, 最終的な色の感覚は赤対緑, 黄対青の 2 対の応答の相対的な值の関数で決まってくる ことが示さ れている. つまり，人間は色を(1)輝度成分，(2)赤緑成分，(3)黄青成分から決定していると考えられている.これ を考慮し，欠点検出率に影響を及ぼすと予測されるパラメータとして輝度コントラストに加え，この赤緑成分と 黄青成分を追加した．赤緑成分については，色の定義に用いた $\mathrm{L}^{*} \mathrm{a}^{*} \mathrm{~b}^{*}$ 表色系の $\mathrm{a}^{*}$ の值，黄青成分については 值と近似できると考えられる. また，輝度コントラストと同样に欠点と背景の差をとる必要があるので，赤緑成 分差を欠点色と背景色の $\mathrm{a}^{*}$ の差をとり $\Delta(\mathrm{r}-\mathrm{g})$, 黄青成分差を欠点色と背景色の $\mathrm{b}^{*}$ の差をとり $\Delta(\mathrm{y}-\mathrm{b})$ として定義す る. さらに, $\Delta(\mathrm{r}-\mathrm{g})$ と $\Delta(\mathrm{y}-\mathrm{b})$ の和を色成分差と定義した. 輝度コントラストを一定間隔で設定し, 欠点の色相の みを変更して実験を行っているので, 輝度差別にみることによって久点の色みのみが欠点検出率へ及ぼす影響を 検討できる. そのために，すべての輝度コントラストと色相角の組み合わせごとに $\Delta(\mathrm{r}-\mathrm{g})$ と $\Delta(\mathrm{y}-\mathrm{b})$ を算出し, 輝 度コントラスト別に色成分差と欠点検出率とを比較したものを図 5 に示す。すべての輝度コントラストにおいて 色成分差と欠点検出率に関連性が認められ, 色成分差が大きいほど欠点検出率が高い傾向にある. しかし, 色成 分差が増加している色相角 $90^{\circ}$ から $135^{\circ}$ にかけては検出率が増加すると予想されるが，実際には検出率は低下し ている.このように色成分差だけでは欠点検出率の変化は説明ができない.

色成分差が検出率に及ぼす影響を検討するために, $\Delta(\mathrm{r}-\mathrm{g})$ と $\Delta(\mathrm{y}-\mathrm{b})$ を説明変数, 欠点検出率を目的変数とした 重回帰分析を行った結果を表 2 に示す． $\Delta(\mathrm{r}-\mathrm{g})$ はすべての輝度コントラストにおいて相関がみられなかったのに 対して $\Delta(\mathrm{y}-\mathrm{b})$ は輝度コントラスト 0.006 から 0.018 までは $1 \%$ 水準, 輝度コントラスト 0.003 は $5 \%$ 水準ときわめて

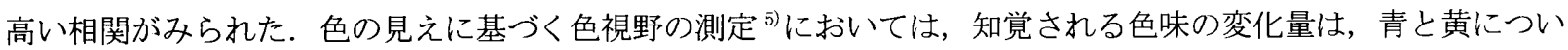
ては中心窩から周辺に広がる際に徐々に減少していき, 赤と緑については中心窩から周辺に広がる際に急激に減 少し，さらに周辺に広がるにつれて徐々に減少していくということが示されている。 $\Delta(\mathrm{y}-\mathrm{b})$ が久点検出率に大き な影響を及ぼした原因の一つがこの色視野の特性の違いにあったのではないかと推察する. 


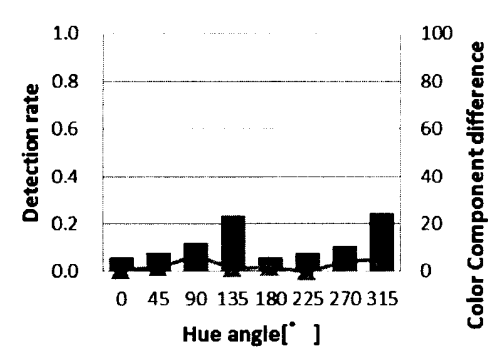

(a)Luminance contrast 0.003

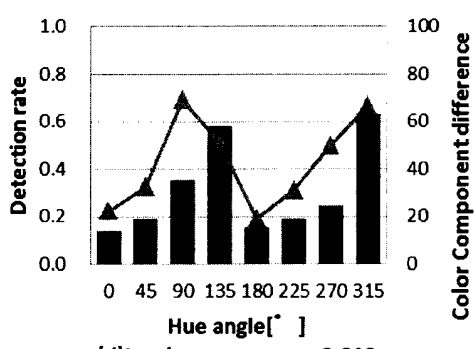

(d)Luminance contrast 0.012

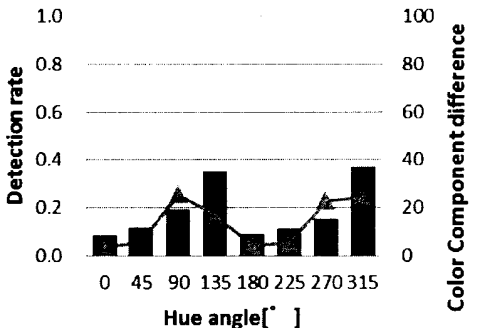

Hue angle[ ${ }^{\circ}$ ]

(b)Luminance contrast 0.006

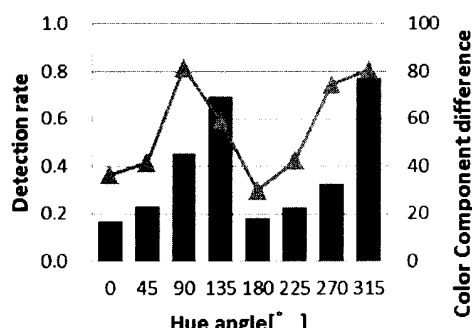

Hue angle[ [ ]

(e)Luminance contrast 0.015

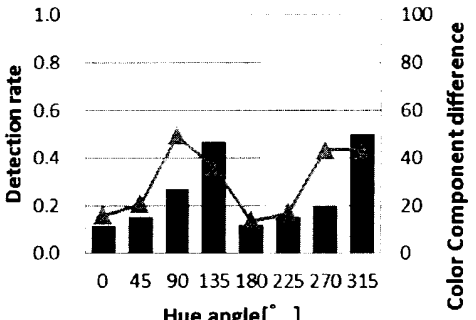

(c)Luminance contrast 0.009

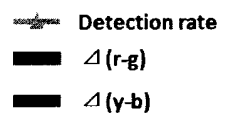

Figure5 Relationship between hue angle, color component contrast and detection rate of each luminance contrast

Table2 Multiple linear regression analysis result of each luminance contrast when detection rate is used as objective variable

\begin{tabular}{|c|c|c|c|c|c|c|}
\hline & & & & & \multicolumn{2}{|c|}{$*: \mathrm{p}<0.1,{ }^{* *}: \mathrm{p}<0.05$} \\
\hline \multicolumn{2}{|c|}{ Term Item } & \multicolumn{5}{|c|}{ Luminance contrast } \\
\hline & & 0.003 & 0.006 & 0.009 & 0.012 & 0.015 \\
\hline \multirow{2}{*}{ coefficient } & $\Delta(\mathrm{r}-\mathrm{g})$ & -0.307 & -0.113 & -0.150 & -0.003 & -0.068 \\
\hline & $\Delta(\mathrm{y}-\mathrm{b})$ & $0.751^{*}$ & $0.963^{* *}$ & $0.977 * *$ & $0.982^{* *}$ & $0.964^{* *}$ \\
\hline \multicolumn{2}{|c|}{ Multiple correlation coefficient } & 0.778 & 0.956 & 0.973 & 0.982 & 0.963 \\
\hline \multicolumn{2}{|c|}{ Determination coefficient } & 0.447 & 0.880 & 0.924 & 0.949 & 0.899 \\
\hline
\end{tabular}

\section{5. 結 铻}

本研究では，ディスプレイ上で周辺視を活用した目視検查をモデル化した実験を行い，尔点の色が欠点検出率 に及ぼす影響を検討した，その結果，輝度コントラストに加えて，尔色が欠点検出率に影響を及ぼすことがわ かった．具体的には，欠点と背景との黄青成分の差が欠点検出率に大きな影響を及ぼすことが明らかになった。 今後の課題としては, 背景色と欠点色の双方が有彩色の場合についても検討する予定である.

近年の科学技術の発展により, きわめて高精度な測定器具が開発されている中, 目視検査は未だに人間の目に 頼らざるを得ない状況にある，本研究は目視検査におうける検出能力に関して検討したが，最終的には検出能力と 判断能力の双方を考慮した研究が必要であると考えられる.

\section{文献}

(1) 佐々木章雄, “アジア域内のものづくり経営”,ワールド・ワイド・ビジネスレビュー, Vol.9,No.2, (2008), pp.208-221.

(2) 菅原隆宏 他，“不良項目別の有効視野範囲と目視角度に着目した新たな周辺視目視検查の作業手順の提案”，日本 経営工学会論文誌, Vol.62,No.4, (2011),pp.154-163.

（3）室山仁美,志田敬介, “欠点の特徵と背景色の相違が欠点検出率に及ぼす影響に関する研究一背景色が無彩色の場合 一”, 日本経営工学会秋季研究大会予稿集, (2010),pp.72-73.

(4) 応用物理学会工学摡話会, “生理光学-眼の光学と色覚-” 朝倉書店, (1975), pp.262-266

（5）関口修利,池田光男，“色の見えに基づく色視野の測定”, 日本眼光学誌，Vol.4,(1982)pp.264-272 